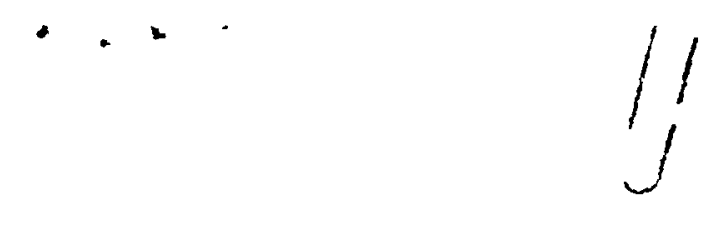

WANL-TME-1961

January, 1969

\title{
TEST SPECIFICATION
}

Graphite Thermal Conductivity Irradiation Test

(Phase 1 - ATJ and POCO AXM 9Q) 37/W415

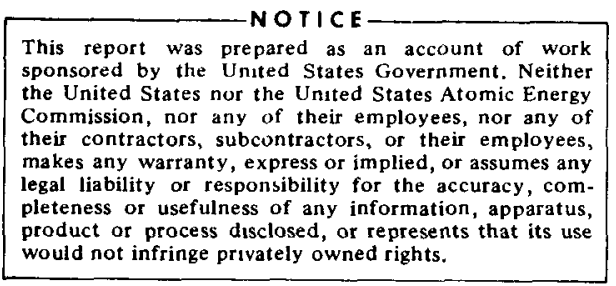

Approved by:

Prepared by:

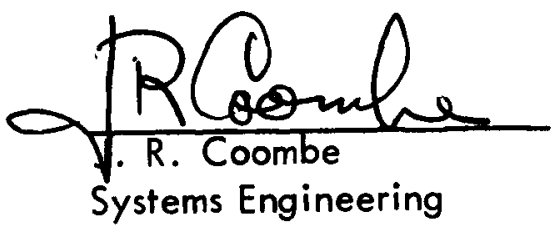

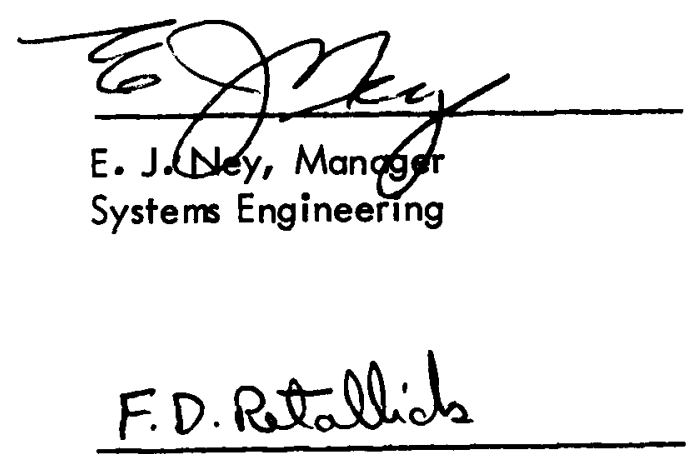

F. D. Retallick, Manager

Systems Management 


\section{DISCLAIMER}

This report was prepared as an account of work sponsored by an agency of the United States Government. Neither the United States Government nor any agency Thereof, nor any of their employees, makes any warranty, express or implied, or assumes any legal liability or responsibility for the accuracy, completeness, or usefulness of any information, apparatus, product, or process disclosed, or represents that its use would not infringe privately owned rights. Reference herein to any specific commercial product, process, or service by trade name, trademark, manufacturer, or otherwise does not necessarily constitute or imply its endorsement, recommendation, or favoring by the United States Government or any agency thereof. The views and opinions of authors expressed herein do not necessarily state or reflect those of the United States Government or any agency thereof. 


\section{DISCLAIMER}

Portions of this document may be illegible in electronic image products. Images are produced from the best available original document. 
1. Experiment Identification
A. Experiment Design Reference - Letter from M. T. Johnson to J. L. Dooling, 12/11/68, Subject: Thermal Conductivity of Irradiated Beryllium and Graphite
B. Sponsor - WANL
C. Test Facility - ORNL-BSR
D. Test Date - May-August 1969

11. Purpose of Experiment

1. To determine thermal conductivity of ATJ and POCO AXM $9 Q$ graphite.
a) From $80^{\circ} \mathrm{K}$ to $2780^{\circ} \mathrm{K}$
b) To $1 \times 10^{19} \mathrm{nvt}$ E $>1 \mathrm{Mev}$

2. To establish correlation between

$K$ and $\rho$ to facilitate future physical property determinations.

3. To determine, cryogenic and room temperature irradiated effects and establish correlation permitting prediction of cryogenically irradiated properties from room temperature irradiations for "normal" graphites.

\section{Drawings}

ORNL Drawing 001D Physical Property Specimens

IV. Equipment List

A. To be provided by WANL

1. Specimens

8 specimens of ATJ "absolute specimen" (Type 1) with grain

8 specimens of ATJ "absolute specimen" (Type 1) against grain 


\section{(W) Astronuclear}

$-2-$

8 specimens of POCO AXM 9Q of "absolute specimen"

3 specimens of ATJ of "comparative longitudinal specimen" (Type 2) with grain

3 specimens of ATJ of "comparative longitudinal specimen" (Type 2) against grain

3 specimens of POCO AXM 9Q of "comparative longitudinal specimen"

B. To be provided by testing agency (ORNL)

1. Test facilities for irradiation of specimens to $10^{19}$ maintaining temperatures at $80^{\circ} \mathrm{K}\left(\sim 140^{\circ} \mathrm{R}\right)$ concurrently measuring $\mathrm{K}$ and $\rho$.

2. Laboratory equipment for determining $K$ and $f$.

V. Test Environment

A. Temperature

1. Irradiation temperature $80^{\circ} \mathrm{K}\left(\sim 140^{\circ} \mathrm{R}\right)\left(\mathrm{LN}_{2}\right)$ and ambient

2. Post irradiation temperatures to $2300^{\circ} \mathrm{K}$

B. Neutron Flux

that necessary to obtain fluences of $1 \times 10^{19}, 5 \times 10^{18}$ and $1 \times 10^{18} \mathrm{nvt}$

VI. Facility Requirements

Thermal conductivity and electrical resistivity apparatus.

VII. Dosimetry

Fast neutron mapping of irradiation facility necessary to define fluence to $\pm 20 \%$. 
VII. Data Requirements
A. Accuracy Requirements (Maximum)
Fluence
$+20 \%$ E $>1 \mathrm{MeV}$
Irradiation Temperature
$+5^{\circ} \mathrm{K}$
Thermal Conductivity
$+10 \%$ reported in watts $/ \mathrm{Cm}^{\circ} \mathrm{K}$
Measurement Temperature
$+5^{\circ} \mathrm{K}$
Electrical Resistivity
$\pm 1 \%$ reported in $\mu \Omega-\mathrm{Cm}$

An error analysis by ORNL is considered part of the project. Established accuracies will be reported.

\section{Test Description}

WANL will fabricate at least 40 specimens of ATJ of the Type 1 design and 20 specimens of POCO AXM 9Q of the Type I design. Room temperature electrical resistivity measurements will be made of these 60 specimens. Eight ( 8 ) specimens of each material will be selected and thermal conductivity and electrical resistivity determined from $\mathrm{LN}_{2}$ temperature to $370^{\circ} \mathrm{K}$. The thermal conductivity and electrical resistivity of the 9 specimens of Type 2 will also be determined from $L_{2}$ temperature to $370^{\circ} \mathrm{K}$ and the total 33 specimens will then be shipped to ORNL.

ORNL will then determine thermal conductivity and electrical resistivity from $80^{\circ} \mathrm{K}$ to $500^{\circ} \mathrm{K}$ for

1) 3 specimens ATJ Type 1 with grain

2) 3 specimens ATJ Type I against grain

3) 3 specimens POCO AXM 9Q Type 1

4) 2 specimens ATJ Type 2 with grain

5) 2 specimens ATJ Type 2 against grain

6) 2 specimens POCO $A X M 9 Q$ Type 2

The schedule in Table 1 will then follow.

See Figure 1 in beryllium thermal conductivity program WANL TME 1960 for format of pictorial data presentation requirement 


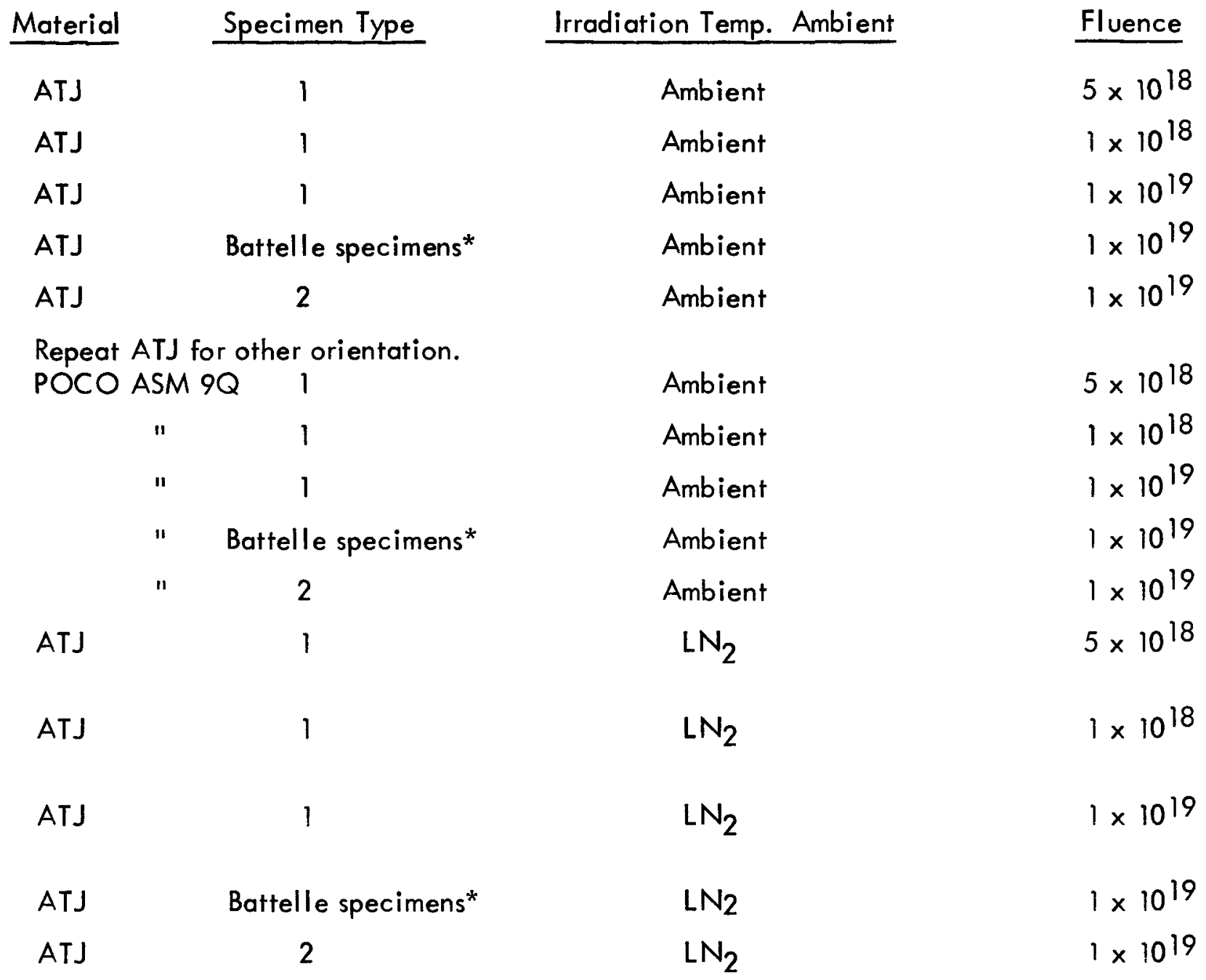

\section{Measurement}

See Figure 1

See Figure 1

See Figure 1

Send to Battelle Memorial Inst.

See Figure 1

See Figure 1

See Figure 1

See Figure 1

Send to Battelle Memorial Inst.

See Figure 1

Monitor K \& $\rho$ during

Irradiation and Figure 1

Monitor $K \& \&$ during

Irradiation and Figure $I$

Monitor $\mathrm{K}$ and $\mathrm{e}$ during Irradiation and Figure

Send to Battelle Memorial Inst.

See Figure 1

Repeat ATJ for other orientation. 


$\begin{array}{cccc}\text { Material } & \text { Specimen Type } & & \text { Irradiation Temp. Ambient } \\ \text { POCO AXM 9Q } & 1 & \mathrm{LN}_{2} & 5 \times 10^{18} \\ " & 1 & \mathrm{LN}_{2} & 1 \times 10^{18} \\ " & 1 & \mathrm{LN}_{2}^{-} & 1 \times 10^{19} \\ " & \text { Battelle specimens* } & \mathrm{LN}_{2} & 1 \times 10^{19} \\ " & 2 & \mathrm{LN}_{2} & 1 \times 10^{19}\end{array}$

Measurement

Monitor K \& during Irradiation and Figure 1

Monitor K \& during Irradiation and Figure 1

Monitor K \& during Irradiation and Figure I

Send to Battelle Memorial Inst.

See Figure 1

*4 1/2" diameter rods each 4" long for expansion, thermal diffusivity and specific heat determinations. 
FIGURE I

Schematic Pulse-Annealing Spectrum

for Graphite

+ Measurement of $\rho$ as a function of pulse time

0 Measurements of $\rho, K, S$ as functions of temperature from $80^{\circ}$ to $500^{\circ} \mathrm{K}$

TEMPERATURE, ${ }^{\circ} \mathrm{K}$

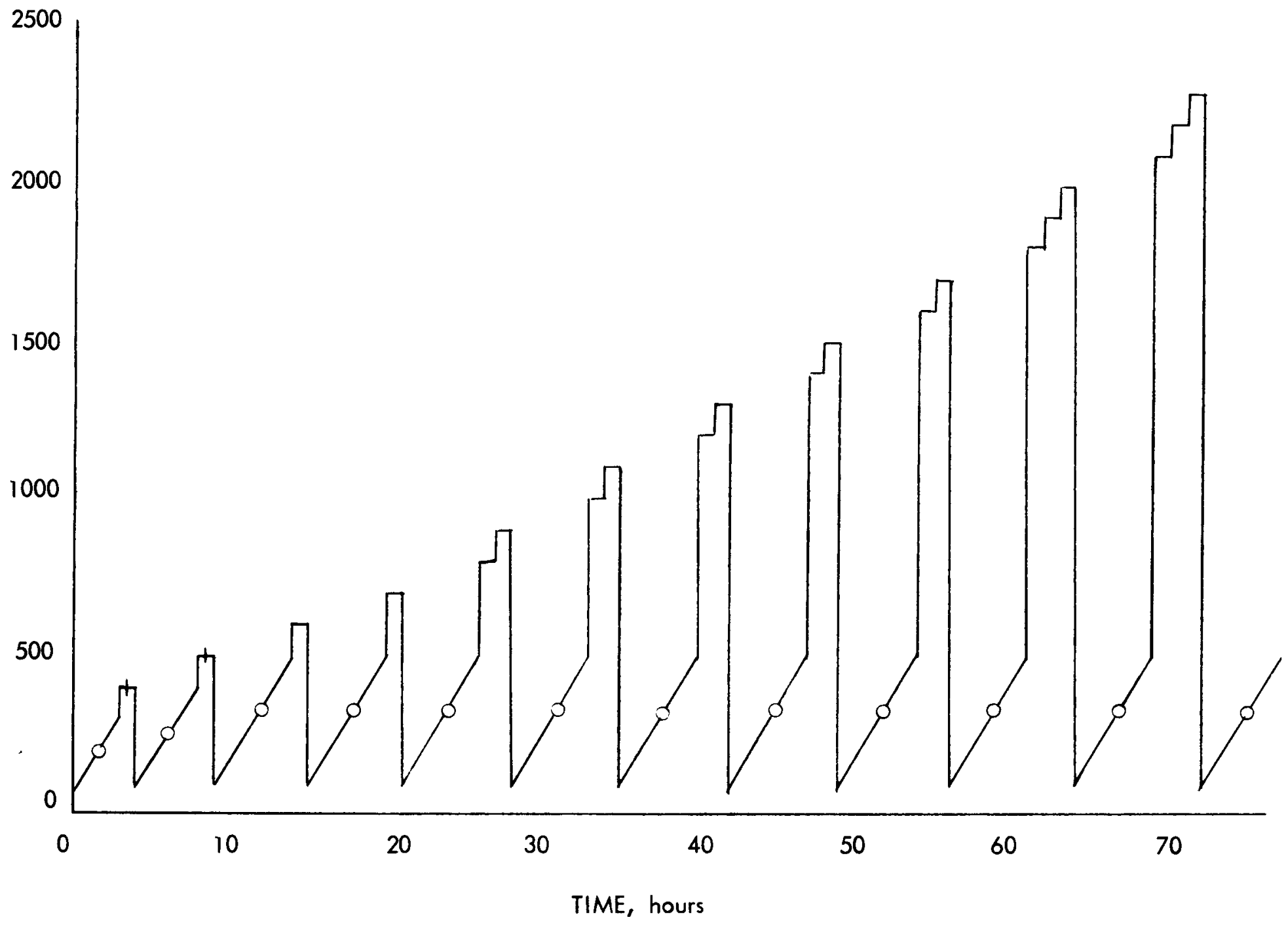

